\title{
SITUATIONAL VARIABLES IN ONLINE VERSUS OFFLINE CHANNEL CHOICE
}

\begin{abstract}
Since the advent and rapid diffusion of the Internet, the subject of consumer channel choice has attracted a large amount of research, mainly focused on the influence of channel, consumer and product category characteristics as its drivers. The interaction between channel choice and the purchase situation has been largely ignored, however. This paper is an attempt to fill this gap by identifying the key purchase situation variables and conducting an experiment to assess their impact on the choice between the traditional retail outlet and the online store. The results show that the key determinants of channel choice relate to time and distance. Distance-to-store and time pressures are among the factors affecting the probability of online purchase. Using a conceptual framework to explore differences in the impact of situational variables across product categories (high/low involvement, search/experience good), we show that distance-tostore has more influence on the likelihood of online purchase in situations involving search goods, while social variables are found to play a role only in the context of highinvolvement goods.
\end{abstract}

\section{Introduction}

For approximately two decades, the range of purchase channels open to consumers has been steadily increasing. Self-service technologies (SSTs), telephone sales and online sales channels have widened the options for retail shoppers, who have adjusted their preferences accordingly, embracing the new channels and increasingly adopting a multichannel approach to shopping (Ansari et al. 2008, Cortiñas et al. 2010, Double Click Inc., 2004).

At the same time, both researchers and marketing professionals have shown a great surge of interest in exploring consumers' behaviour in relation to new purchase channels and their channel preferences for specific products. This preliminary research has revealed that the primary determinants of intended and actual use of a given 
purchase channel are consumers' perceptions of channel characteristics (Gehrt and Yan 2004, Neslin et al. 2006, Huang and Opperal 2006) the characteristics of the underlying technologies (Meuter et al. 2000), personal attitudes toward using them (Zhou et al. 2007), consumers' socio-demographic, psychological and psychographic characteristics (Dabholkar and Bagozzi 2002, Gehrt and Yan 2004, Neslin et al. 2006, Zhou et al. 2007), consumers' experience and use of technology (Meuter et al. 2000, Zhou et al. 2007) and product characteristics (Gehrt and Yan 2004, Cortiñas et al. 2010).

Nevertheless, these variables do not appear to explain all of the observed variation in channel choice behaviour patterns across different purchase occasions. They appear to fail to fully explain why a given consumer sometimes buys a specific product in a brick-and-mortar store, and at other times uses the Internet or another channel.

Belk (1974, 1975) offers a possible explanation for this. Purchase-channel choices depend on the context in which they are taken. The new flexibility of options, although potentially benefiting consumers, may present a new challenge to marketing managers, by adding an element of unpredictability and incoherence to consumer behaviour whereby every purchase by every consumer is potentially unique.

Thus, to improve resource allocation and productivity, while enhancing the customer experience, successful advertising, promotion and merchandising campaigns require an awareness and deep understanding of the relationship between the purchase situation and channel choice.

For the above reasons, and to fill gaps identified by authors such as Verhoef and Lagerak (2001) and Hand et al. (2009), this paper explores the effect of situational variables on channel choice by asking not "which one?” but "when?”.

We place the focus on the decision whether to shop in a traditional retail store or via the Internet, which is the most frequent choice problem faced by multichannel shoppers (Cortiñas et al. 2010, Double Click Inc., 2004).

Despite repeated confirmation of the product-channel relationship in numerous channel choice studies (Gehrt and Yan 2004, Nicholson et al. 2002, Zhou et al. 2007, among others) category-driven variation in the impact of situational variables on channel preferences has remained virtually unexplored. Nevertheless, some studies have shown that the potential moderating effect of product category must always be 
considered when exploring online shopping behaviour patterns (Morrison and Roberts 1998, Zhou et al. 2007). A further aim of this study, therefore, is to test for variation in the impact of situational variables across product categories.

The Internet's capacity to convey only written and certain forms of pictorial information has put into question its suitability as a shopping channel and led to research resulting in a multitude of product classifications based on intrinsic, perceived or other attributes, such as tangibility, cost, degree of differentiation, complexity, etc. (Alba et al. 1997, Degeratu et al. 2000, Peterson et al. 1997, among others). This paper focuses on two of the main taxonomies used in channel choice research since the advent of the Internet: one that sorts products by level of involvement (high or low), and another that sorts them into search or experience goods.

Based on the above considerations, this paper pursues three objectives. The first is to explore the role played by five broad categories of situational variables in channel choice decisions. The second is to compare, by experimental means, the roles of different situational variables in the probability of online purchase. The third is to use the same experiment to explore the moderating effect of product category on the impact of situational factors.

The paper is organized as follows. In section 2, we review the literature analyzing the impact of situational variables on channel choice and explain how our paper fits into this line of research. In section 3, we describe our exploratory study of the relative importance of a set of situational variables prior to selecting the variables for our experiment and formulating hypotheses for them. In section 4, we present a conceptual framework to explore the moderating effect of product category on the impact of the selected variables. In section 5, we provide details of the empirical specification and the methodology used to test the hypotheses. Finally, we present the main findings, provide some conclusions, and indicate the implications for retail managers.

\section{Situational factors in the choice between the physical and the virtual store.}

Situational variables are "all those factors particular to a time and place of observation which do not follow from a knowledge of personal (intra-individual) or stimulus (choice alternative) attributes” (Belk 1974, p. 157). 
Consumer behaviour is largely driven by these situational variables or shopping contexts, which can influence their information search (Gehrt and Shim 2002, Mattson and Dubinksy 1987), preferences, product assessment and product choice (Belk 1974, 1975), price sensitivity (Wakefield and Inman 2003), their preferred store layout (Van Kenhove et al. 1999), their use of in-store self-service technology (Dabholkar and Bagozzi 2002, Wang et al. 2012) and, of course, their choice of purchase channel (Nicholson et al. 2002, Hand et al. 2009, among others).

Situational variables can have a direct influence on channel choice decisions (Nicholson et al. 2002, Gehrt and Yan 2004, Hand et al. 2009, Chintagunta et al. 2012, Oppewal et al. 2012). Some authors (Hand et al. 2009) even suggest that channel choice is an erratic process that is more circumstantially than cognitively driven. Moreover, situational variables can also influence the decision indirectly through the consumer's value perceptions of the different channels, the relevance of their respective features, or their compatibility with an individual shopping style (Gehrt and Yan 2004, Huang and Oppewal 2006, Verhoef and Langerak 2001). These variables may also cause consumers to hesitate to adopt a particular purchase channel, even if they feel comfortable with the technology, able to see its advantages over other alternatives or positively inclined towards it (Forman et al. 2009).

Situational variables can be grouped as follows (Belk 1975): 1. Variables relating to the physical surroundings in which the choice process takes place. These include distance-to-store, crowdedness, the weather, and retail store environment variables (background music, tidiness, etc.). 2. Time-related variables, which include time-of-day or day-of-the-week, urgency of purchase, product availability and time pressures. 3. Variables relating to the social environment, such as the presence of others at the time of the decision, the apparent roles of such persons, and the chance for social interaction. 4. Variables relating to antecedent states, including temporary physical or mental states, moods, fatigue, etc. 5. Task-definition variables, which include the cognitive and motivational aspects of the purchase situation (whether the item is required as a gift or for personal use, etc.).

In Table 1, we use Belk's taxonomy to classify empirical studies that use some means to measure the effects of situational variables on channel choice, which is the line of research into which this paper fits. The general impression is that time-related factors have attracted more interest than other situational dimensions. It is also apparent 
that previous analyses have involved a single product category. There appear to have been no previous attempts to test for category-related variation in the influence of situational variables on channel choice. One study (Gehrt and Yan, 2004) considers two product categories, books and apparel, representing a search good and an experience good, respectively, but the analysis treats product category as a situational variable in itself. 
TABLE 1. Review of the literature

\begin{tabular}{|c|c|c|c|c|c|}
\hline Authors & $\begin{array}{l}\text { Dependent } \\
\text { variable }\end{array}$ & $\begin{array}{l}\text { Relationship } \\
\text { established between } \\
\text { situational variables } \\
\text { and channel choice } \\
\end{array}$ & $\begin{array}{l}\text { Situational } \\
\text { variables* }\end{array}$ & $\begin{array}{l}\text { Channels } \\
\text { considered }\end{array}$ & Product \\
\hline $\begin{array}{l}\text { Verhoef and } \\
\text { Langerak } \\
\text { (2001) }\end{array}$ & $\begin{array}{l}\text { Online supermarket } \\
\text { purchase intention }\end{array}$ & $\begin{array}{l}\text { Effect mediated by } \\
\text { relative advantages } \\
\text { online vs. offline, } \\
\text { compatibility with } \\
\text { shopping styles and } \\
\text { complexity }\end{array}$ & $\begin{array}{l}\text { Time } \\
\text { (D2) } \\
\text { Physical } \\
\text { (D1) }\end{array}$ & Online & Foods \\
\hline $\begin{array}{l}\text { Nicholson et } \\
\text { al (2002) }\end{array}$ & Channel choice & $\begin{array}{l}\text { Direct } \\
\text { effect(exploratory) }\end{array}$ & $\begin{array}{l}\text { Situation variables } \\
\text { of five types }\end{array}$ & $\begin{array}{l}\text { Physical stores } \\
\text { Internet } \\
\text { Catalogue }\end{array}$ & Apparel \\
\hline $\begin{array}{l}\text { Gehrt and } \\
\text { Yan (2004) }\end{array}$ & Channel preference & $\begin{array}{l}\text { - Direct effect } \\
\text {-Effect mediated by } \\
\text { the importance of } \\
\text { respective channel } \\
\text { characteristics }\end{array}$ & $\begin{array}{l}\text { Time pressures } \\
\text { (D2) } \\
\text { Gift or personal } \\
\text { use (D5) }\end{array}$ & $\begin{array}{l}\text { Physical stores } \\
\text { Internet } \\
\text { Catalogue }\end{array}$ & $\begin{array}{l}\text { Apparel } \\
\text { Books }\end{array}$ \\
\hline $\begin{array}{l}\text { Huang and } \\
\text { Oppewal } \\
\text { (2006) }\end{array}$ & $\begin{array}{lr}\text { Channel } & \text { choice } \\
\text { online } & \text { versus } \\
\text { physical store }\end{array}$ & $\begin{array}{l}\text { Effect mediated by } \\
\text { consumers' value } \\
\text { perceptions in online } \\
\text { versus offline sales }\end{array}$ & $\begin{array}{l}\text { Availablity of time } \\
\text { (D2) } \\
\text { Travel time (D2) } \\
\text { Proposed purchase } \\
\text { (D5) }\end{array}$ & $\begin{array}{l}\text { Physical stores } \\
\text { Internet }\end{array}$ & Foods \\
\hline $\begin{array}{l}\text { Forman, } \\
\text { Ghose and } \\
\text { Goldfarb } \\
(2009)\end{array}$ & $\begin{array}{l}\text { Channel choice } \\
\text { (channel } \\
\text { substitution) }\end{array}$ & $\begin{array}{l}\text { Moderating effect of } \\
\text { type-of-product } \\
\text { within category } \\
\text { considered and price } \\
\text { on channel choice }\end{array}$ & Distance (D1) & $\begin{array}{l}\text { Online } \\
\text { Physical stores }\end{array}$ & Books \\
\hline $\begin{array}{l}\text { Hand et al } \\
(2009)\end{array}$ & $\begin{array}{lr}\text { Adoption } & \text { and } \\
\text { abandonment } & \text { of } \\
\text { online } & \text { versus } \\
\text { physical } & \text { store } \\
\text { shopping } & \\
\end{array}$ & Direct effect & $\begin{array}{l}\text { Change in living } \\
\text { situation (D4) } \\
\text { Time pressures } \\
\text { (D2) }\end{array}$ & $\begin{array}{l}\text { Online } \\
\text { Physical stores }\end{array}$ & Foods \\
\hline $\begin{array}{l}\text { Chintagunta, } \\
\text { P. K., Chu, J. } \\
\text { and } \\
\text { Cebollada, } \\
\text { (2012) }\end{array}$ & $\begin{array}{ll}\begin{array}{l}\text { Channel } \\
\text { online }\end{array} & \text { choice } \\
\text { offline } & \text { versus }\end{array}$ & Direct effect & $\begin{array}{l}\text { Distance (D1) } \\
\text { Day of the week } \\
\text { (D2) } \\
\text { Bad weather (D1) } \\
\text { Purchase } \\
\text { characteristics } \\
\text { (D5) }\end{array}$ & $\begin{array}{l}\text { Online } \\
\text { Physical stores }\end{array}$ & Foods \\
\hline $\begin{array}{l}\text { Oppewal, H., } \\
\text { Tojib, D.R. } \\
\text { and } \\
\text { Louvieris } \\
\text { (2012), }\end{array}$ & $\begin{array}{l}\text { Channel choice for } \\
\text { travel information } \\
\text { search and actual } \\
\text { booking }\end{array}$ & Direct effect & $\begin{array}{l}\text { Time pressures } \\
\text { (D2) } \\
\text { Expected } \\
\text { expenditure (D5) }\end{array}$ & $\begin{array}{l}\text { Agency } \\
\text { Internet-at home } \\
\text { Internet-cybercafé } \\
\text { Brochures } \\
\text { Other physical } \\
\text { outlets }\end{array}$ & Travel \\
\hline This paper & $\begin{array}{ll}\text { Channel } & \text { choice } \\
\text { online } & \text { versus } \\
\text { physical store }\end{array}$ & $\begin{array}{l}\text { - Direct effect } \\
\text {-Effect moderated by } \\
\text { product category }\end{array}$ & $\begin{array}{l}\text { - Five types of } \\
\text { situational } \\
\text { variables in the } \\
\text { exploratory study } \\
\text { - Seven variables } \\
\text { in the experimental } \\
\text { design (3D1, 2D2, } \\
\text { 2D3) }\end{array}$ & $\begin{array}{l}\text { Online } \\
\text { Physical stores }\end{array}$ & $\begin{array}{l}\text { Apparel } \\
\text { Books } \\
\text { Computers } \\
\text { Tickets }\end{array}$ \\
\hline
\end{tabular}

*D1: physical surroundings, D2. Time-related variables, D3: social environment, D4: antecedent states, D5: Task definition (Belk 1975)

\section{Selection of situational variables. Research phase 1.}

There is a wide range of potential situational variables and a wide range of empirical methods to address our research objectives. We therefore performed an exploratory 
study to identify which situational variables might more decisively influence the consumer's decision to use one channel versus another.

Basing our selection on a review of the literature including Belk (1975) and past research on the role of situational variables in channel choice (see Table 1), we selected 21 such variables for use in a questionnaire, where subjects were required to rate how much or how little these factors influence them when selecting a purchase channel, irrespective of product category. They responded by indicating their level of agreement with a series of statements using a 5-point scale (ranging from strongly disagree to strongly agree). The questionnaire also included questions designed to capture information on frequency of Internet purchase across different product categories.

The questionnaire was administered in a purposely-designed venue to aid respondents' concentration. A trained interviewer was on hand to ensure the correct understanding of all the questions and each participant completed the scoring in isolation from the rest.

The survey took place in November 2009 in the city of Pamplona, capital of Navarra, Spain.The questionnaire was put to a gender-balanced sample of 85 consumers who had at some time purchased products via the Internet. The age distribution of this sample was as follows: $26.5 \% 24$ years of age or less, 38.56\% between 25 and 34, approximately $15 \%$ between 35 and 40 and the remainder over 40 .

The results, given in Table 2, indicate the percentage of participants per response category, per statement. Since exploratory study makes no specific hypotheses as to whether the influence of the variables is positive or negative, central trend measures are of no use in identifying the most influential variables. Dispersion measures also serve little purpose, since we wish to examine not only variables with a strong unidirectional impact and therefore low dispersion (such as those that strongly encourage online purchase) but also variables that may differentiate between consumers and therefore have high dispersion (such as those that drive online purchase in some consumers and physical-store purchase in others). Thus, because of the ordinal scale of the variables, we identified those with the highest and lowest scores and selected the six with the highest percentages of extreme values. The last column in Table 2 gives the sum of the extreme values of the scale. 


\section{TABLE 2.Results of the exploratory study (in percentage terms)}

\begin{tabular}{|c|c|c|c|c|c|c|c|}
\hline 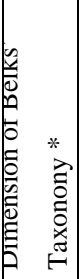 & & 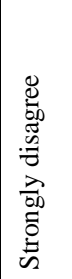 & 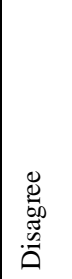 & 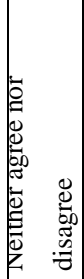 & 芯 & 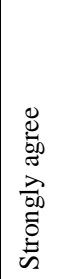 & 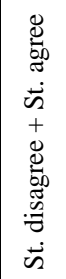 \\
\hline D2 & On-line shopping is a good option when real stores are closed. & 3.6 & 3.6 & 13.1 & 42.9 & 36.9 & 40.5 \\
\hline D3 & I do not like shopping on-line because I do not get to speak to anyone. & 35.3 & 35.3 & 18.8 & 8.2 & 2.4 & 37.7 \\
\hline D1 & $\begin{array}{l}\text { When the stores selling the product I am looking for are a long way from } \\
\text { my home or place of work, I am likely to purchase on-line. }\end{array}$ & 2.4 & 12.9 & 14.1 & 36.5 & 34.1 & 36.5 \\
\hline D2 & On-line shopping is a good option when time is short. & 4.7 & 4.7 & 17.6 & 43.5 & 29.4 & 34.1 \\
\hline D1 & $\begin{array}{l}\text { An untidy store where it is hard to find what I'm looking for could make } \\
\text { me opt for the Internet }\end{array}$ & 4.7 & 12.9 & 20 & 37.6 & 24.7 & 29.4 \\
\hline D3 & $\begin{array}{l}\text { If I have someone to go with, I prefer to shop in real stores rather than on- } \\
\text { line. }\end{array}$ & 2.4 & 15.3 & 20.2 & 36.2 & 25.9 & 28.3 \\
\hline D4 & On-line stores are good when you are not in the mood to go out shopping. & 20.0 & 24.7 & 35.3 & 12.9 & 7.1 & 27.1 \\
\hline D5 & When I have money to spare, I go on the net to buy myself a little treat. & 15.3 & 20.0 & 40.0 & 15.3 & 9.4 & 24.7 \\
\hline D4 & On-line stores are the better option when you are tired or ill. & 14.1 & 22.4 & 34.1 & 18.8 & 10.6 & 24.7 \\
\hline D3 & When I expect the shops to be crowded, I prefer to purchase on-line. & 4.8 & 23.8 & 22.6 & 29.8 & 019 & 23.8 \\
\hline D1 & $\begin{array}{l}\text { Difficulty with parking or the anticipation of traffic jams can make me } \\
\text { purchase on-line. }\end{array}$ & 7.1 & 18.8 & 21.2 & 36.5 & 16.5 & 23.6 \\
\hline D3 & I like real stores because you can get help from the staff. & 7.1 & 15.3 & 18.2 & 42.9 & 16.5 & 23.6 \\
\hline D5 & Real stores are better when you want to buy yourself a little treat. & 7.1 & 10.7 & 40.5 & 27.4 & 14.3 & 21.4 \\
\hline D1 & In bad weather, I shop on-line to avoid going out. & 12.9 & 43.5 & 27.1 & 8.2 & 8.2 & 21.1 \\
\hline D3 & I like going to real stores because I meet people I know. & 17.6 & 25.9 & 38.8 & 14.1 & 3.5 & 21.1 \\
\hline D5 & $\begin{array}{l}\text { When you are shopping for a large number of items, it is better to go to a real } \\
\text { store where you can get everything at once, rather than have to use several } \\
\text { different web sites. }\end{array}$ & 8.2 & 16.5 & 34.1 & 28.2 & 12.9 & 21.1 \\
\hline D1 & $\begin{array}{l}\text { If I find the store atmosphere (fittings, decoration, lighting) pleasing, I will } \\
\text { probably choose to shop there rather than on-line. }\end{array}$ & 10.6 & 12.9 & 31.8 & 35.3 & 9.4 & 20.0 \\
\hline D1 & $\begin{array}{l}\text { If I like the web-page layout, I prefer to purchase online rather than in a } \\
\text { traditional store. }\end{array}$ & 2.4 & 20.2 & 38.1 & 23.8 & 15.5 & 17.9 \\
\hline D2 & $\begin{array}{l}\text { I prefer to shop in a real store to avoid the lengthy delivery times with on-line } \\
\text { purchases. }\end{array}$ & 1.2 & 18.8 & 22.5 & 42.2 & 15.3 & 16.5 \\
\hline D5 & It is better to buy gifts in real stores. & 2.4 & 14.1 & 29.4 & 40.0 & 14.1 & 16.5 \\
\hline D4 & On-line stores are better than real stores for planned purchases. & 3.5 & 23.5 & 50.6 & 11.8 & 10.6 & 14.1 \\
\hline
\end{tabular}

*D1: physical surroundings, D2. Time-related variables, D3: social environment, D4: antecedent states, D5: Task definition (Belk 1975) 
The six variables selected included two physical factors: store tidiness and distanceto-store; two temporal factors: time of purchase and time pressures; and two social factors: shopping alone/in the presence of others and the chance for social interaction. Since one of these variables involved physical store layout, it was decided that the experimental design should also include virtual store layout to better balance the criteria.

The fact that no antecedent or task-definition dimensions figured among the key variables challenged their relevance, which could only be confirmed by means of a more conclusive scale-dimension analysis. Nevertheless, the three most relevant dimensions (physical, temporal and social) are consistent with those that emerged in an exploratory study of factors influencing online purchase patterns by Nicholson et al (2002).

\section{Situational factors in channel choice: Role and moderators}

This section offers a generic description of the effects we expect to find in our analysis of the influence of the selected variables on channel choice and provides details of our theoretical model for the moderating effect of product category. Figure 1 summarizes the research model.

Products can be classified according to their different attributes, such as tangibility, cost, degree of differentiation, complexity, etc. (Alba et al. 1997, Degeratu et al. 2000, Peterson et al. 1997, Zhou et al. 2007, among others). This paper focuses on two of the main taxonomies used in previous channel-choice studies: one that classifies them by the level of product involvement (high or low), another that sorts them into search or experience goods.

The literature has shown consumer involvement with a product category to be a key factor in overall purchase behaviour (e.g. Laurent and Kapferer 1985; Zaichkowsky 1985). Product involvement is a consumer-defined construct whereby products are defined as high- or low-involvement goods based on the perception of the majority of consumers (Beatty and Smith 1987, Wang et al. 2006). Generally speaking, highinvolvement goods tend to be of high monetary value and/or low purchase frequency, and thus involve greater risks for the consumer.

Differences in involvement levels across product categories have a variety of effects on purchase behaviour. These include the length of time and effort spent on the 
purchase process (Zaichkowsky 1985), the number of attributes taken into consideration when assessing the product (Beatty and Smith 1987), the level of satisfaction expected from the purchase (Antil 1984) and consumers' information demand (Krugman 1965). The product involvement level also influences consumers’ post-purchase behaviour, in aspects such as the complexity of their cognitive reactions and store and brand loyalty (Quester and Lim 2003, Westbrook 1987).

Another product classification commonly used in channel choice studies sorts attributes according to their value as quality indicators and differentiates between search and experience goods, based on their dominant type of attribute (Nelson 1970). Search attributes can be identified prior to purchase, while experience attributes can only be assessed after purchase or during consumption (Nelson 1974). Consumer behaviour will therefore differ according to the type of product being considered for purchase. Thus, with an experience good, the emphasis is more likely to be on extrinsic attributes, such as price, brand and recommendations, as cues to product quality and the consumer will want to feel or taste the product (Wright and Lynch 1995). Furthermore, since certain attributes of experience goods are difficult to assess (Bone 1995), consumers will be willing to pay higher prices to offset some of the increased perceived risk involved in purchase decisions for this category of goods, based on the assumption of a direct relationship between price and quality (Rao and Bergen 1992). Clothing and fresh food products are examples of experience goods, because their attributes (durability, fabric quality, freshness, flavour...) cannot be fully evaluated before use or consumption. The attributes of search goods, in contrast, are easy to assess even before use (Jain et al. 2000) without having to try them. Since their quality is easier to verify a priori, the purchase decision is less risky. Books and dried food products are considered search goods because the blurb on the back cover or information on the packet makes it much easier to judge the contents (Grewal et al. 2004). 
Figure 1. Research Model

Situational Variables

Product category

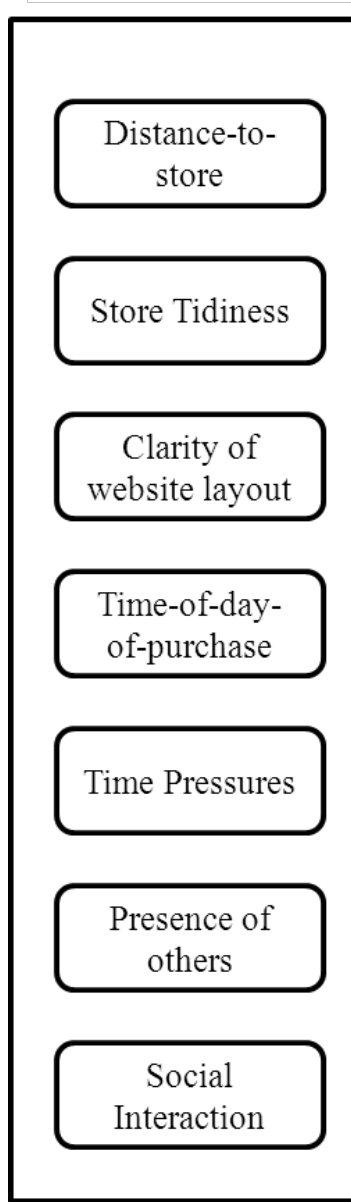

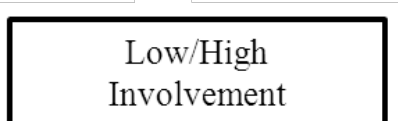

Involvement

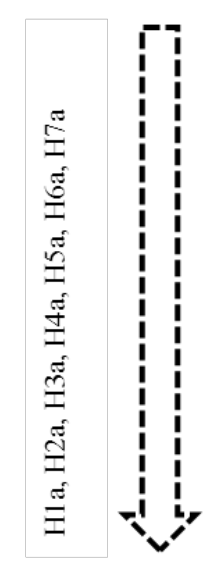

Experience/Search products

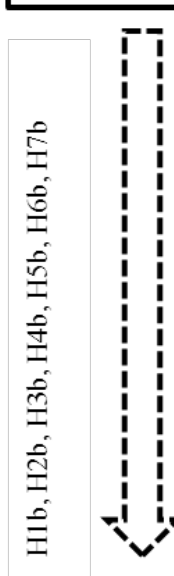

Probability of online/offline purchase

\subsection{Situational variables in the physical environment}

Situational variables in the physical environment, such as distance-to-store or retail store environment variables, influence channel choice potentially more than any other kind (Nicholson et al 2002).

\section{Distance-to-store}

The literature relating to the online purchase decision and the related options (Meuter et al 2000) reports that one of the main advantages of the new shopping channels is the ability to purchase goods from any location. This effectively removes the distance obstacle, making the Internet a viable alternative for purchases that would otherwise involve a long trip.

The easy accessibility of online purchase channels saves the consumer time, money and effort (Akaah et al 1995) thus offering greater convenience than physical stores 
(Schröder and Zaharia 2008). Oppewal et al. (2012) recently obtained that distance had a negative effect on the use of traditional purchase channels.

According to Downs' (1961) consumer efficiency theory, consumers seek to minimize purchase costs, which include time as well as money. They will therefore judge each channel by the costs it involves. Based on a spatial competence model designed to explore online-offline channel substitution in a multichannel environment (Balasubramanian 1998, among others), we assume, furthermore, that the offline purchase decision obliges the consumer to consider the fixed costs associated with getting to the store. These will depend on where the decision takes place and will increase with the distance between purchaser and vendor, whereas the fixed costs are invariable for all online purchases.

Thus, the further the store, the greater the utility and the higher the probability of online purchase. This has been confirmed by recent studies, such as Chintagunta et al. 2012 and Forman et al. 2009, the first of which estimates that a household can save an average of 0.47 Euros per kilometre by shopping for groceries online rather than offline.

As far as product category is concerned, the broad literature on variation in consumer involvement across product categories has so far not considered how this factor might affect the interaction of situational variables with channel choice. Predictably, however, the role of situational variables will co-vary with product involvement, given the influence of the latter on the evolution of the purchase process. When it comes to distance-to-store, for instance, the purchase process for highinvolvement products takes longer and consumers are willing to travel further to ensure a correct choice (Zaichkowsky 1985). We can therefore assume that distance-to-store is less important than it would be for a low-involvement product, because consumers will expect a more positive purchase experience as a reward for the extra effort of going further afield.

As in the comparative analysis of consumer behaviour towards high- versus lowinvolvement goods, the broad literature analysing consumer behaviour towards search versus experience goods has given little consideration to possible variation driven by situational variables. Nevertheless, previously documented differences between purchase processes for experience versus search goods give reason to assume that situational variables will have a different impact in each context. For instance, the greater risk involved in decisions regarding experience goods will incentivize 
consumers to try to see, touch and test the product they are about to purchase. This suggests that distance-to-store will be less of an issue in the experience goods than in the search goods context, because, if consumers are confident that a more accurate product-quality assessment can be made in situ, they will be readier to face any potential travel costs.

Based on the above, we state our first hypothesis and two sub-hypotheses. Hypothesis 1 refers to the generic influence of distance on channel choice and Hypotheses 1a and 1b refer to the moderating effect of product category:

H1: As distance-to-store increases, so does the probability of online purchase.

H1a: The effect of distance-to-store on the probability of online purchase is more pronounced in the low-involvement than the high-involvement context.

H1b: The effect of distance-to-store on the probability of online purchase is more pronounced in the search goods than in the experience goods context.

Tidiness in the shopping environment

Keen interest among researchers in the effect of traditional retail store environment variables on buyer behaviour has led to a wealth of empirical evidence (Turley and Milliman 2000). Retail store environment variables, both external (entrances, display windows, parking availability, etc.) and internal (temperature, music, colour schemes, decoration, cleanliness, placement and grouping of merchandise, product displays, etc.) appear to influence consumers' choice of store, length of visit, amount of money spent, number of products purchased, degree of impulse buying, etc. (Nicholson et al. 2002, Turley and Milliman 2000).

Traditionally, this line of research has viewed retail store environment variables as being subject to the control of the retail manager, who can adjust them to influence customer behaviour. It must also be noted, however, that the customers themselves affect the shopping environment with their noises, smells, behaviour, etc. Despite the best efforts of sales staff, the products in some stores can be found in disarray due to the behaviour of previous shoppers. Store untidiness can make it difficult to find the desired product, induce stress, diminish quality perception, prompt a rejection response and cause the customer to leave without completing a purchase. Exploring this issue, Oppewal et al. (2012) found that consumers are more likely to approach the channels they perceive to offer higher quality. 
This factor, however, has less relevance in relation to the purchase of highinvolvement products, where the consumer's main aim is to make the right choice, regardless of the effort required, and more relevance in relation to that of lowinvolvement products, where the consumer wishes to minimise the time and effort spent searching for and comparing products. We therefore expect store tidiness to have less impact on channel choice in the high-involvement purchase context.

As already stated, a tidy store will always ease the decision-making process, provided there is some congruence between how consumers categorize products in their minds and how they are categorized in the purchase channel layout (Morales et al. 2005). This relevance of this factor is fairly similar for both search and experience goods, since the consumer always appreciates a sufficient degree of organization as to be able to compare the available options (Lurie 2004).

Thus, we propose the following hypothesis:

H2: The more untidy the traditional store, the higher the probability of online purchase.

H2a: The effect of store tidiness on online purchase probability is stronger in low-involvement than in high-involvement contexts.

H2b: The effect of store tidiness on online purchase probability is equal in both search and experience goods contexts.

There is as much empirical evidence regarding the impact of environmental variables on buyer behaviour in the online context as there is in the traditional store context (Manganari et al. 2009).

One online environment variable is website design, which usually determines the layout and navigability of the web page (Lociacono et al. 2002, Montoya-Weiss et al. 2000).

Well organized websites offering clear information layout, simple purchase process instructions, ease of navigation, etc. drive both intended and actual purchase levels (Loiacono et al. 2002, Montoya-Weiss et al. 2000, Nicholson et al. 2002, Richard 2005).

When it comes to product category effects, either in the purchase of high involvement versus low involvement products or in that of experience versus search 
goods, the reasoning for store tidiness applies equally to the clarity of website layout. A well-organized web page makes it easier to find the desired product type and compare the options. This factor is less important in the high- than in the low-involvement context, but has fairly equal importance for both search and experience goods, since clarity of organization is always desirable for easy comparison of the available options.

This leads us to the following hypotheses:

H3: The clearer the website layout, the higher the probability of online purchase.

H3a: The effect of the clarity of website layout on the probability of online purchase is stronger in the low-involvement than in the high-involvement context.

H3b: The effect of the clarity of website layout on the probability of online purchase is equal in both the search and experience goods contexts.

\subsection{Time-related situational variables}

Due to their effect on convenience, time and distance variables have been repeatedly mentioned in the comparison of online versus offline service output levels (KaufmanScarborough and Lindquist 2002, Nicholson et al. 2002). As already noted, the time variables considered in this paper are time-of-day-of-purchase and time pressures.

Time-of-day-of-purchase

The range of purchase channel options depends on the time of day the decision is being made (Black et al. 2002, Meuter et al. 2000; among others). Opening hours in traditional stores are usually shorter than the 24-hour shopping available on the Internet. Online shopping allows consumers greater independence by removing external restrictions and enabling them to shop at any time of day or night (Schröder and Zaharia 2008). This is particularly important in countries with very strictly regulated shopopening hours.

Furthermore, consumers approach stores hoping to gather the information they need in order to complete a purchase. Fear of not having enough time to research the products and thus making too hasty a purchase may therefore discourage them from shopping in a traditional store very near to closing time. In terms of time, therefore, the convenience of a purchase channel is a matter of consumer perception (Kleijnen et al. 2007). 
This time factor can be expected to play a more decisive role in low-involvement contexts. In high-involvement contexts, consumers will try to select the best store for their purchase, even if faced with less convenient opening hours, whereas, in lowinvolvement contexts, they will be more likely to take the easier option. The amount of effort they are willing to make will vary according to the time of day.

Similarly, time-of-day has a more decisive impact on channel choices involving search goods. Decisions relating to experience goods take longer because of the greater risk and information-processing involved. Thus, it is reasonable to assume that proximity to store closing time matters.

The above leads us to state the following hypothesis:

H4: The nearer it is to store closing-time, the greater the probability of online purchase.

H4a: The time-of-day effect on the probability of online purchase is stronger in low-involvement than in high-involvement contexts.

H4b: The time-of-day effect on the probability of online purchase is stronger in search than in experience goods contexts.

Time pressures

Perceived time pressures on task completion may modify purchase behaviour. Busy consumers may decide to make a purchase online rather than offline because of the time it saves (Black et al. 2002, Meuter et al. 2000,Verhoef and Langerak, 2001) and the enjoyment it provides (Huang and Opperal 2006). This was, indeed, the conclusion reached by authors such as Hand et al. (2009), Huang and Opperal (2006) and Verhoef and Langerak (2001) in the context of grocery shopping; whereas Gehrt and Yan (2004) found no such relationship in the book or apparel categories.

A further aspect of the above is the time spent waiting to be served or standing at the cash-out. Customers tend to be impatient and to dislike waiting. They look for the shortest queue and seek quick-purchase options, even when their preference is for another product, if this avoids waiting (Dabholkar and Bagozzi 2002, Wang et al. 2012).

The same reasoning applies for time pressures as given above for time-of-day effects. Time pressures will make consumers more likely to take the easier option in 
low-involvement contexts. They will also have a more decisive impact in the search than in the experience goods context.

The above leads us to the following hypothesis:

H5: The greater the time pressures, the higher the probability of online purchase.

H5a: Time pressures have more impact on the probability of online purchase in low-involvement than in high-involvement contexts.

H5b: Time pressures have more impact on the probability of online purchase in search than in experience goods contexts.

\subsection{Social dimensions of the purchase context}

The literature has traditionally highlighted the social motives for shopping in traditional retail stores and demonstrated the influence of this factor on consumer behaviour (Nicholson et al. 2002, Sommer et al. 1992).

There is sufficient evidence to suggest that the presence of other people at the time of purchase has a positive effect. This kind of social support might predictably reduce the perceived risk and uncertainty associated with the purchase process, thereby increasing the consumer's confidence in making the right decision (Borges et al. 2010, Kiecker and Hartman 1994, Nicholson et al. 2002). Information, advice or moral support from others in the store may reduce the anxiety and stress caused by an unfamiliar situation and thereby heighten the buyer's sense of control in the process. In the same vein, Raghunathan and Corfman (2006) found that the presence of others might be desirable because it enables human bonding and enhances shared experiences and the perception of having made the right choice.

The purchase experience may even transcend the actual nature of the product being purchased (Alba et al. 1997), in which case the social support will also have a hedonic effect (enjoyment, fun) (Borges et al. 2010, Nicholson et al.2002) leading consumers in traditional stores to linger longer and make more purchases (Sommer et al. 1992).

Social support can come from a friend or relative accompanying the shopper or from a casual stranger. The effectiveness of the uncertainty-reducing mechanism varies according to the closeness of the bond. According to Kiecker and Hartman (1994), support from close relatives or friends is assumed to reduce perceived risk, particularly that of a social or symbolic nature, while support from strangers tends to be more 
functional. The hedonic effect is more likely if the shopper receives support from a friend than if accompanied by a relative or shopping alone.

Sometimes, however, the presence of strangers in a purchase situation in a traditional store context can have a negative effect, potentially causing the buyer to feel stress, loss of control, or social anxiety (e.g., Hui and Bateson 1991). Social anxiety may influence attitudes towards available purchase channels, causing consumers to focus on the advantages of those options that free them from having to deal with crowds, and thus swaying their usage intentions. This was the conclusion reached by Dabholkar and Bagozzi (2002) in their research on the choice between a touch screen and a verbal order when ordering fast food.

There are also occasions on which people have neither the need nor the wish to speak to others in order to obtain information or verify their choices, in which case the presence of others may even prove annoying (Raghunathan and Corfman 2006). Such individuals may derive limited satisfaction from social bonding or support for their own decisions.

Finally, the presence of others may reduce purchase effectiveness by distracting the purchaser's attention away from the tasks involved in the purchase process, and may explain some people’s preference to shop alone (Borges et al. 2010).

Thus, consumers who are particularly averse to social interaction when shopping are very likely to prefer online shopping, which is commonly known for its non-social nature (Alba et al. 1997, Meuter et al. 2000, Nicholson et al. 2002). The online purchase experience lacks warmth and sociability (Gefen and Straub 2003) tending to be more impersonal, anonymous and automated (van der Heijden 2003, Wang and Emurian 2005).

Online retailers therefore face the challenge of making virtual stores more socially enriching (Kumar and Benbasat 2002, Hassanein and Head 2007). Zhu et al. (2006) use the term "collaborative online shopping" to describe the experience of shopping online together with one or more remotely located "shopping buddies". Web characteristics that might evoke a sense of collaborative online shopping include chats (Kumar and Benbasat 2002), human assistants (Aberg and Shahmenhri 2000,Hostler et al. 2005), virtual communities (Kumar and Benbasat 2002), socially-enriching pictorial and 
textual content (Gefen and Straub 2003) and telepresence (Zhu et al. 2006). These features are not yet widely available in existing online purchase channels, however.

Without denying the enjoyment to be had from using the Internet and its potential for providing a collaborative shopping experience, we assume, in line with the literature, that physical stores have greater capacity than virtual stores to address the socio-recreational needs of the shopper.

The above leads us to the following hypothesis:

H6: The probability of online purchase is lower if a friend or relative is present at the time of the channel choice decision.

H7: The effect of the opportunity for social interaction on the probability of online purchase varies across consumers and product categories.

One of the phenomena associated with the purchase of high-involvement goods is consumers' tendency to consult a range of product information sources (Antil 1984; Krugman 1965). In this case, channels enabling social interaction are perceived to be better than those that do not. Such channels are less well-rated for the purchase of products in low-involvement categories, however, where the aim is to minimize time and effort, and where having to engage in social interaction might even prove bothersome. Similar reasoning applies with respect to the issue of shopping alone or in the presence of others. The presence of a companion enhances the experience of shopping in a traditional retail store for a high-involvement product, but does quite the opposite if the purchase involves a low-involvement product. Therefore:

H6a: The presence of others has more negative impact on the probability of online purchase in low-involvement than in high-involvement contexts.

H7a: The effect of the opportunity for social interaction on the probability of online purchase is negative in low-involvement contexts.

Finally, we expect the impact of socio-environmental variables to vary between search goods and experience goods. It has been widely demonstrated, for example, that the opinions of others are particularly important to the consumer shopping for experience goods. This is because, by providing a source of indirect experience of sensory attributes that extrinsic cues fail to convey, they help to reduce the perceived risk associated with the purchase of experience goods (West and Broniarczyk 1998). 
Conversely, King and Balasubramanian (1994) find that consumers will probably select a search good based on their own criteria. Therefore, the positive impact of the opportunity to confer with others and the presence of others will be greater in the context of experience goods than in that of search goods.

This leads us to the next hypotheses:

H6b: The presence of others has more negative impact on the probability of online purchase in the context of experience goods than in that of search goods.

H7b: The effect of the opportunity for social interaction on the probability of online purchase is positive in the context of experience goods.

\section{Situational variables and product category in channel choice decisions. Research} phase 2

\subsection{Definition of the variables}

We test the above hypotheses by experimental means. We first define levels for the 7 variables selected in phase 1, using two levels for each variable to limit the number of possible scenarios and thereby the complexity of the analysis and to reduce error in the results (Wang and $\mathrm{Li}, 2002$ ). This study uses a between-subject design to examine the moderating effect of product category and a within-subject design to examine the effect of the situational variables. We begin with a 7-factor model with two levels of each factor to test the effects of the situational variables.

The factor levels are as follows:

- Store Tidiness: very untidy / very tidy

- Clarity of website layout: very poor / very good

. Distance-to-store: 20 minutes by car from consumer's residence to the town centre /consumer resident in town centre .

- Time-of-day-of-purchase: 3 hours before closing time /15 minutes before closing time. 
- Time pressures: a lot to do /nothing to do.

- Presence of others at time of channel choice decision: alone / with someone else.

- Opportunity for social interaction in the store: someone to talk to in the store/ no one to talk to in the store.

All possible combinations of these factors (7) and their different levels (2) give a total of 128 scenarios $\left(2^{7}\right)$. Since every respondent will be faced with the different choice scenarios, it is necessary to find a way to keep the scenario rating task within reasonable limits without losing any valuable response variation data. An orthogonal design enables the researcher to reduce the rating task required of survey respondents while still identifying all estimable effects (Ortúzar et al. 2000). An orthogonal design uses a given number of stimuli in which all estimable effects are uncorrelated (Louviere et al. (2000), thus enabling estimation of all the main effects. For the case in hand, SPSS Statistics21.0 software is used to generate a set of 8 highly representative choice scenarios from the 128 possibilities.

Figure 2 shows one of the 8 cards presented to the participants, where the levels are as follows:

- Store tidiness: very tidy.

- Clarity of website layout: very poor.

- Distance-to-store: 20 minutes by car from consumer's residence to town centre.

- Time-of-day-of-purchase: 3 hours prior to closing time

- Time pressures: a lot to do.

- Presence of others at time of channel choice decision: alone.

- Opportunity for social interaction in store: no one in store to talk to. 


\section{FIGURE 2. Sample scenario presented to survey participants}

Imagine you have read everything on your bookshelf and you realise you will have nothing to read at the weekend. It is Tuesday and you decide to buy a new book. It is 5 pm (3 hours before closing time) and you are alone at home, which is a 20 - minute drive from the town centre. Although you have a lot to do this afternoon, you know a bookshop that is usually very well-organized although you are unlikely to find anyone there to talk to. You also know a website where you could buy a book, but the layout is not very clear.

Supposing the offer and the prices to be similar in both cases, you have a total of 10 points to distribute between the two options in order to rate the probability of their being your choice of channel for the purchase of a book in the above situation:

\begin{tabular}{|l|c|}
\hline & Points \\
\hline The Internet & \\
\hline The bookshop & \\
\hline TOTAL & 10 \\
\hline
\end{tabular}

\subsection{Choice of product categories}

Two important methodological reasons require us to base this study on selected product categories. Firstly, since one of the objectives is to analyse the moderating effects of product category (high/low involvement, search/experience good) we need to select a product from each category. Secondly, we need to ensure the validity of the data we obtain from the survey by linking each choice scenario to a particular product category for the sake of authenticity.

The selection of product categories for this study is based on three criteria. Firstly, they must be among those most frequently purchased online, to ensure the survey participants' familiarity with the channel-choice scenario. Our guidelines are provided by the 12th AIMC Internet user survey (AIMC 2010). Secondly, they must include both search and experience goods. Thirdly, the selected products must cover different consumer involvement levels.

The selected products were books (search good, low involvement), T-shirts (experience good, low involvement), plane tickets (search good, high involvement) and personal computers (experience good, high involvement). According to the results of our exploratory analysis, the levels of penetration for these four categories are high (books: 75\%, fashion: 56\%, IT products: 63.1\%, airline tickets: 88.1\%).

We used a between-subjects design to control for the product category effect without creating too complex a rating task. In this case, any more than 8 choice 
scenarios per respondent could result in practice, sensitization, and carry-over that may limit interpretation of results (Greenwald, 1976).

\subsection{Questionnaire design}

As well as asking participants to state their channel choice preferences in eight different choice scenarios for a single product category, the questionnaire is designed to solicit other types of data. For the four products considered, the first section requires respondents to rate on a scale of $0-10$, ( $0=$ totally unsuitable; $10=$ highly suitable $)$ the suitability of the traditional store versus the virtual store for their purchase (Moore and Benbasat, 1996). This provides an indication of their frequency of purchase for each product (number purchased in the last year) and their frequency of purchase per channel (using percentages per product/per channel). Questions to ascertain respondents' sociodemographic data, including age, gender, marital status, size of hometown, income level, etc. appear inserted between one scenario and the next.

\subsection{Procedure}

An online data collection mode can be deemed appropriate for use with the target population (consumers who had at some time made an online purchase). Specialized professionals adapted the experimental design and supplementary questionnaire to the online survey mode. Two critical decisions were taken to ensure the validity of the results. Firstly, to prevent respondent fatigue and minimise any learning effect, the scenarios were presented to each respondent in random order and the various sections of the supplementary questionnaire were inserted between one scenario and the next. Secondly, instead of presenting every respondent with all the channel choice scenarios (8) and all the product categories (4), which would have meant 32 choice scenarios in all, a single category was randomly assigned to each respondent (Malhotra, 1982). They were then asked to rate the probability of their opting for the online store or the physical store in each case by distributing 10 points between the two.

\subsection{The sample}

The target population for this study includes any Spanish resident who has ever made an online purchase. A company specializing in market research collected the data using a computer-assisted web-interviewing procedure (CAWI) in April 2010.

We extracted a representative sample of 1600 online shoppers. This sample included 400 participants per product category and reflected the same gender and age quotas used 
in the Survey on Information and Communication Technology Equipment and Use in Households 2009.

$57.5 \%$ of the sample was male. The age distribution was approximately $16.5 \% 16-$ 24 years, 35\% 25-34, 26\% 35-44, 15\% 45-54, and the remainder 55 or over. $91.5 \%$ were resident in towns with populations of 5,000 or over. $58.8 \%$ had no children. Roughly 54\% were educated to university level or beyond, $39 \%$ had a secondary education and the rest a primary education or none at all (See Table 3).

TABLE 3. Personal characteristics of survey respondents. Descriptive statistics.

\begin{tabular}{|c|c|c|c|}
\hline \multirow[t]{2}{*}{ Variables } & \multirow[t]{2}{*}{ Categories } & \multicolumn{2}{|c|}{ Total } \\
\hline & & $N$ & $\%$ \\
\hline \multirow[t]{2}{*}{ Sex } & Male & 920 & 57.5 \\
\hline & Female & 680 & 42.5 \\
\hline \multirow[t]{6}{*}{ Age } & 16-24 years & 262 & 16.4 \\
\hline & 25-34 years & 563 & 35.2 \\
\hline & 35-44 years & 416 & 26.0 \\
\hline & 45-54 years & 244 & 15.3 \\
\hline & 55-64 years & 95 & 5.9 \\
\hline & $>65$ years & 20 & 1.3 \\
\hline \multirow[t]{7}{*}{ Size of hometown } & Pop. $<1,000$ & 30 & 1.9 \\
\hline & Pop. 1,000-4,999 & 106 & 6.6 \\
\hline & Pop. 5,000-19,999 & 251 & 15.7 \\
\hline & Pop. 20,000-99,999 & 371 & 23.2 \\
\hline & Pop. 10,0000-499,999 & 385 & 24.1 \\
\hline & Pop. 500,000-1,000,000 & 151 & 9.4 \\
\hline & Pop. >1,000,000 & 306 & 19.1 \\
\hline \multirow[t]{7}{*}{ Number of children } & None & 940 & 58.8 \\
\hline & One & 263 & 16.4 \\
\hline & Two & 307 & 19.2 \\
\hline & Three & 63 & 3.9 \\
\hline & Four & 20 & 1.3 \\
\hline & Five & 6 & 0.4 \\
\hline & Seven & 1 & 0.1 \\
\hline \multirow[t]{5}{*}{ Education } & None & 2 & 0.1 \\
\hline & Primary & 104 & 6.5 \\
\hline & Secondary & 628 & 39.3 \\
\hline & Higher & 866 & 54.1 \\
\hline & & 1600 & \\
\hline
\end{tabular}


The following details regarding purchase frequency across product categories in the above sample are worth noting. Books and T-shirts showed the highest frequency of purchase and the lowest number of respondents reporting zero purchases in the last year. The reverse was found for the IT product category. While $42.56 \%$ of those surveyed had bought more than four books, 55\% more than 4 T-shirts, and only 8\% (approx.) had bought neither of these products, almost 30\% had bought no IT products at all and only about 10\% had bought more than four IT items.

The online channel is the most frequent choice for the purchase of airline tickets, while the traditional store is still the preferred channel for the remaining products.

\subsection{Data analysis}

To analyse the impact of the situational variables on channel choice, we use a Binary Logit model (Ben-Akiva and Lerman 1985, Kamakura and Russell 1989) where the dependent variable is the probability of the online channel being the preferred option in a given situation. A number of behavioral and demographic factors drawn from the supplementary questionnaire are included as control variables.

According to this model, in each channel choice scenario, for an individual h, the utility of the online store is defined as follows:

$$
V_{h, j}=\text { Intercept }+\sum_{i}^{7} \beta_{1 i} \text { Factor }_{\mathrm{i}}+\sum_{p}^{4} \beta_{2 p} \text { Behavioral }_{p}+\sum_{w}^{5} \beta_{3 w} \text { Demographic }_{w}+\varepsilon_{h, j}
$$

Where:

h: online shopper $\mathrm{h}$

$\mathrm{j}$ : the scenario presented to each respondent (1-8)

i: a situational variable, such as (1) distance-to-store, (2) store tidiness, (3) organization of website layout, (4) time-of-day-of- purchase, (5) time pressures, (6) opportunity for social interaction during the purchase process, and (7) presence of others during the purchase.

p: a behavioural variable, such as (1) channel-product compatibility per product category, (2) purchase frequency per category,(3) purchase frequency per product and (4) online purchase frequency per product.

w: a demographic variable, such as (1) gender,(2) age,(3) size of hometown, (4) number of children and (5) level of education. 
$\beta_{1 \mathrm{i}}, \beta_{2 \mathrm{p}}, \beta_{3 \mathrm{w}}$ : parameters that capture the impact of each of the above variables.

Following the assumptions of the Binary Logit Model (Hensher et al 2005), the probability of online purchase by individual $h$ in channel choice scenario $j$ can be written as:

$$
\operatorname{Prob}(\text { online })_{h, j}=\frac{\exp \left(V_{h, j}\right)}{1+\exp \left(V_{h, j}\right)}
$$

Given that the subjects in our sample fall into four clear groups (purchasers of high/low involvement goods and purchasers of experience/search goods) possible between-group differences in variance could affect the scale parameters. Although this does not affect interpretation of the aggregate parameters, it could complicate the testing of the relative effects of the various product categories. To overcome this problem, we estimate four different models (one for each category) in addition to the original aggregate model. The coefficients of these four models are compared using Swait and Louviere's (1993) pairwise test to confirm or rule out the existence of overall differences in consumer behaviour across the four categories (high versus low involvement and experience versus search goods).

\section{Results and discussion}

Table 4 shows the results of the multinomial logit model for all the survey participants. Coefficients at the 5\% level of significance are highlighted. This is the model used to test the general hypotheses H1-H7. The first noticeable result is the negative constant, which shows that our respondents prefer traditional stores to shopping online.

Among the situational variables, we find that physical environmental and time factors have a significant impact on the probability of online purchase, which increases with distance-to-store ( $\mathrm{H} 1$ confirmed; $\beta=0.097$ ); decreases with physical store tidiness (H2 confirmed; $\beta=-0.333$ ), and increases with clarity of website layout (H3 confirmed; $\beta=0.531$ ). Consumers are also more likely to select the online channel within 15 minutes to store closing time (H4 confirmed; $\beta=0.178$ ) or when they are very busy (H5 confirmed; $\beta=0.097)$. It is not possible to draw any conclusions regarding the socioenvironmental variables, despite their producing the expected signs.

When it comes to behavioural variables, consumers' perceived suitability of each product category for online purchase and their frequency of online purchase both have a 
positive impact on the probability of online purchase. However, overall frequency-ofpurchase per product category is significant only with respect to computers. The more often consumers buy a computer, the less likely they are to purchase it online.

Finally, the only notable finding for the role of the socio-demographic variables is the significance of the number of children and level of education, both of which act as drivers of online purchase behaviour. 
TABLE 4.Multinomial Logit Results per product category ${ }^{*}$

\begin{tabular}{|c|c|c|}
\hline & Variables & Coefficients (z values) \\
\hline & Constant & $-1.631(-11.293)$ \\
\hline \multirow[t]{10}{*}{ Situational variables } & Physical dimensions & \\
\hline & Distance-to-store & $0.097(2.423)$ \\
\hline & Store tidiness & $-0.333(-8.263)$ \\
\hline & Clarity of website layout & $0.531(13.125)$ \\
\hline & Time dimensions & \\
\hline & Time-of-day-of-purchase & $0.178(4.431)$ \\
\hline & Time pressures & $0.097(2.420)$ \\
\hline & Social dimensions & \\
\hline & Presence of others & $-0.010(-0.266)$ \\
\hline & Social interaction & $0.025(0.625)$ \\
\hline \multirow[t]{4}{*}{ Product/channel compatibility } & Books & $0.068(5.363)$ \\
\hline & T-shirts & $0.084(5.511)$ \\
\hline & Computer & $0.105(6.327)$ \\
\hline & Ticket & $0.115(6.562)$ \\
\hline \multirow[t]{4}{*}{ Overall purchase frequency } & Books & $0.009(0.354)$ \\
\hline & T-shirts & $-0.048(-1.862)$ \\
\hline & Computer & $-0.107(-2.248)$ \\
\hline & Ticket & $0.041(1.074)$ \\
\hline \multirow[t]{4}{*}{ Online purchase frequency } & Books & $0.007(5.953)$ \\
\hline & T-shirts & $0.008(4.065)$ \\
\hline & Computer & $0.009(6.813)$ \\
\hline & Ticket & $0.009(8.278)$ \\
\hline \multirow[t]{7}{*}{ Socio-demographic variables } & Gender & $-0.077(-1.879)$ \\
\hline & Age & $-0.003(-1.652)$ \\
\hline & Size of home town & $0.057(1.281)$ \\
\hline & Children & $0.106(2.098)$ \\
\hline & Level of education & $0.108(4.439)$ \\
\hline & $\mathrm{N}=1413$ & \\
\hline & $\begin{array}{l}\log =-7058.310 \\
1.96 .\end{array}$ & \\
\hline
\end{tabular}




\subsection{The impact of situational variables in high-versus low-involvement products}

Table 5 presents the results by involvement levels, where it emerges that consumers prefer to shop in traditional retail stores irrespective of their level of involvement with the product.

\section{TABLE 5. Multinomial Logit Results by involvement level}

\begin{tabular}{|c|c|c|c|c|}
\hline & & Low involvement & High involvement & $\begin{array}{l}\text { T-test for low vs. } \\
\text { high involvement** }\end{array}$ \\
\hline \multicolumn{2}{|l|}{ Variables } & $\begin{array}{l}\text { Coefficients } \\
\text { (z values) }\end{array}$ & $\begin{array}{l}\text { Coefficients } \\
\text { (z values) }\end{array}$ & \\
\hline \multicolumn{2}{|l|}{ Constant } & $-1.484(-7.817)$ & $-2.256(-10.686)$ & 0.145 \\
\hline \multicolumn{5}{|l|}{$\begin{array}{l}\text { Situational } \\
\text { variables }\end{array}$} \\
\hline \multirow{3}{*}{$\begin{array}{l}\text { Physical } \\
\text { dimensions }\end{array}$} & Distance-to-store & $0.099(-1.771)$ & $0.108(-1.854)$ & 0.102 \\
\hline & Store tidiness & $-0.280(5.002)$ & $-0.393(6.717)$ & 0.621 \\
\hline & $\begin{array}{l}\text { Clarity of } \\
\text { website layout }\end{array}$ & $0.415(7.415)$ & 0.658 (11.222) & -1.700 \\
\hline \multirow[t]{2}{*}{ Time dimensions } & $\begin{array}{l}\text { Time-of-day-of- } \\
\text { purchase }\end{array}$ & $0.242(-.333)$ & $0.116(2.000)$ & 1.786 \\
\hline & Time pressures & 0.109 (1.962) & $0.078(1.351)$ & -0.537 \\
\hline \multirow[t]{2}{*}{$\begin{array}{l}\text { Social } \\
\text { dimensions }\end{array}$} & $\begin{array}{l}\text { Presence of } \\
\text { others }\end{array}$ & $-0.074(-1.328)$ & $0.053(0.912)$ & -1.465 \\
\hline & Social interaction & $-0.065(-1.175)$ & $0.118(2.025)$ & -2.029 \\
\hline \multicolumn{2}{|l|}{$\begin{array}{l}\text { Product/channel } \\
\text { compatibility }\end{array}$} & 0.084 (8.249) & 0.125 (8.657) & $-1.187-$ \\
\hline \multicolumn{2}{|l|}{$\begin{array}{l}\text { Overall Purchase } \\
\text { frequency }\end{array}$} & $-0.010(-0.418)$ & $0.003(0.099)$ & -0.302 \\
\hline \multicolumn{2}{|l|}{$\begin{array}{l}\text { Online purchase } \\
\text { frequency }\end{array}$} & 0.007 (6.837) & 0.012 (15.005) & -0.007 \\
\hline \multirow{7}{*}{$\begin{array}{l}\text { Socio- } \\
\text { demographic } \\
\text { variables }\end{array}$} & Gender & $-0.166(-2.885)$ & $0.062(1.050)$ & -2.626 \\
\hline & Age & $-0.010(-3.216)$ & $0.004(1.444)$ & -0.009 \\
\hline & $\begin{array}{l}\text { Size of home } \\
\text { town }\end{array}$ & $-0.033(-0.532)$ & 0.117 (1.808) & -1.450 \\
\hline & $\begin{array}{l}\text { Number of } \\
\text { children }\end{array}$ & 0.192 (2.777) & $0.022(0.307)$ & 1.711 \\
\hline & $\begin{array}{l}\text { Level of } \\
\text { education }\end{array}$ & $0.170(5.000)$ & $0.045(1.312)$ & 2.710 \\
\hline & & $\mathrm{N}=713$ & $\mathrm{~N}=700$ & $\chi_{17}^{2}=56.816$ \\
\hline & & $\mathrm{Lg}=-3651.2$ & $\mathrm{Lg}=-3414.307$ prob & 0.000 \\
\hline
\end{tabular}


Comparison of the logit models for low- and high-involvement goods using Swait and Louviere's test (1993) reveals global parameter differences. This suggests the need for separate pairwise testing of the equality of the coefficients between the lowinvolvement model and the high-involvement model with the adjusted t statistics (BenAkiva and Lerman, 1985).

Three situational variables, namely, physical store tidiness; clarity of website layout; and time-of-day-of-purchase are found to have an impact in both the high- and lowinvolvement categories. The more untidy the store, the more likely the consumer will purchase the desired goods online; a choice which is also driven by website clarity. Purchases being considered 15 minutes before store-closing time are also more likely to be made online. As far as cross-category variance is concerned, H1a remains unconfirmed, since the effect of distance-to-store is similar for both high and lowinvolvement goods. $\mathrm{H} 2 \mathrm{a}$ and $\mathrm{H3a}$ also remain unconfirmed, since the lack of any significant differences between the two involvement levels refutes the idea that store tidiness or clarity of website layout play a more important role in purchase decisions involving for low-involvement goods.

$\mathrm{H} 4 \mathrm{a}$ and $\mathrm{H} 5 \mathrm{a}$ regarding the effects of time-related situational variables also remain unconfirmed, since the differences between the coefficients are not significant. In the individual models, however, time pressures are observed to influence the choice of channel for low-involvement purchases, while having no significant impact for highinvolvement purchases.

Our hypotheses for the last group of variables, relating to social interaction, state that, for the purchase of low-involvement goods, the chance of social interaction will decrease the probability of online purchase. Partial confirmation is found for H6a, and for H7a, no negative effects are found but the signs of the two coefficients are different.

The findings for the behavioural variables show that, while the perceived suitability of the product category for online purchase and frequency of online purchase both have a positive impact in both involvement levels, frequency of purchase fails to achieve significance in either of them.

Finally, none of the socio-demographic variables considered had a significant impact in channel choice for high-involvement purchases, whereas all except size of hometown played a significant role in channel choice for low-involvement purchases. 
6.2. The impact of situational variables in the purchase of experience and search goods

Table 6 enables us to see that, analogous to the results for effects across involvement levels, consumers' preference for the traditional store over the virtual store holds for both experience and search good purchases.

The results of Swait and Louviere's test (1993) to compare the search and experience logit models confirm the null hypothesis of scale parameter equivalence. This removes the need for an adjustment factor since it is possible to compare the original model parameters using the t statistic (Ben-Akiva and Lerman 1985).

The first factor in the search category is distance. Thus, online purchase probability in the case of a search good increases with distance-to-store, a variable that our conceptual framework identifies as predictably playing a more important role in the purchase of search goods than in that of experience goods. Since this factor has no significant impact in the purchase of experience goods, we have only partial confirmation of H1b.

The observed effect of the physical-environmental variables is that online purchase probability increases as store tidiness decreases and website clarity increases. The online channel is also the more likely choice during the last 15 minutes before store closing time. The observed absence of differences between product categories nevertheless precludes confirmation of H2b and H3b.

Although H4b asserts that time-of-day-of-purchase has a more decisive impact in the search product context, our findings reveal that it has equal impact in the search and experience contexts. Since time pressures do not appear to matter in either of these contexts, we are unable to confirm H5b.

Hypotheses H6b and H7b, which posit that the socio-environmental variables have different impact in the purchase contexts of both search and experience goods, remain unconfirmed because the non-significance of the two coefficients prevents any clear conclusions. 


\section{TABLE 6.Multinomial Logit Results for search versus experience goods *}

\begin{tabular}{|c|c|c|c|c|}
\hline & & Experience & Search & $\begin{array}{c}\text { T-test } \\
\text { experience } \\
\text { vs. search }\end{array}$ \\
\hline Variables & & $\begin{array}{l}\text { Coefficients } \\
\text { (z values) }\end{array}$ & $\begin{array}{l}\text { Coefficients } \\
\text { (z values) }\end{array}$ & \\
\hline Constant & & $-1.604(-6.959)$ & $-1.741(-9.490)$ & 0.466 \\
\hline \multicolumn{5}{|l|}{ Situational variables } \\
\hline \multirow[t]{4}{*}{ Physical dimensions } & Distance-to-store & $0.089(1.468)$ & $0.106(1.983)$ & -0.209 \\
\hline & Store tidiness & $-0.311(-5.130)$ & $-0.349(-6.479)$ & 0.468 \\
\hline & Clarity of website & $0.506(8.332)$ & $0.547(10.122)$ & -0.504 \\
\hline & layout & & & \\
\hline \multirow[t]{2}{*}{ Time dimensions } & $\begin{array}{l}\text { Time-of-day-of- } \\
\text { purchase }\end{array}$ & $0.172(2.848)$ & $0.184(3.416)$ & -0.148 \\
\hline & Time pressures & $0.101(1.674)$ & $0.093(1.737)$ & 0.099 \\
\hline \multirow[t]{2}{*}{ Social dimensions } & Presence of others & $-0.037(-0.620)$ & $0.008(0.157)$ & -0.554 \\
\hline & Social interaction & $-0.010(-0.166)$ & $0.053(0.992)$ & -0.776 \\
\hline $\begin{array}{l}\text { Product/channel } \\
\text { compatibility }\end{array}$ & & $0.093(7.855)$ & $0.090(7.423)$ & 0.176 \\
\hline Overall Purchase frequency & & $-0.050(-1.832)$ & $-0.035(-1.438)$ & -0.403 \\
\hline Online purchase frequency & & $0.009(8.076)$ & $0.012(17.602)$ & -2.206 \\
\hline \multirow{7}{*}{$\begin{array}{l}\text { Socio-demographic } \\
\text { variables }\end{array}$} & Gender & $-0.027(-0.448)$ & $-0.108(-1.979)$ & 0.976 \\
\hline & Age & $-0.006(-1.877)$ & $0.000(0.124)$ & -1.311 \\
\hline & Size of home town & $0.063(0.952)$ & $0.080(1.312)$ & -0.188 \\
\hline & $\begin{array}{l}\text { Number of } \\
\text { children }\end{array}$ & $0.094(1.264)$ & 0.079 (1.178) & 0.148 \\
\hline & Level of education & $0.120(3.281)$ & 0.107 (3.290) & 0.265 \\
\hline & & $\mathrm{N}=613$ & $\mathrm{~N}=800$ & $\begin{array}{l}\chi_{17}^{2}= \\
9.166\end{array}$ \\
\hline & & $\operatorname{Lg}=-3112,922$ & $\mathrm{Lg}=-3975.990$ & prob $=0.935$ \\
\hline
\end{tabular}

* Shading indicates z values higher than 1.96 . 
As far as behavioural variables are concerned, perceived suitability of the product for online purchase and online purchase frequency have an impact in both these categories. The effect is positive in both cases. Interestingly, the t statistic reveals significant category-related variation in the impact of online purchase frequency, which is stronger for search goods than for experience goods. Thus, the probability of online purchase is higher in consumers reporting higher frequency of Internet usage, especially if the desired item is a search good.

Finally, with respect to the socio-demographic variables, level of education proves to be a significant factor in the choice of channel for the purchase of both experience and search goods, while a gender effect is observed only in the purchase of search goods.

A final summary of the findings is given in Figure 3, where the confirmed hypotheses are outlined in bold.

\section{Figure 3.Research phase 2. Hypotheses and results}

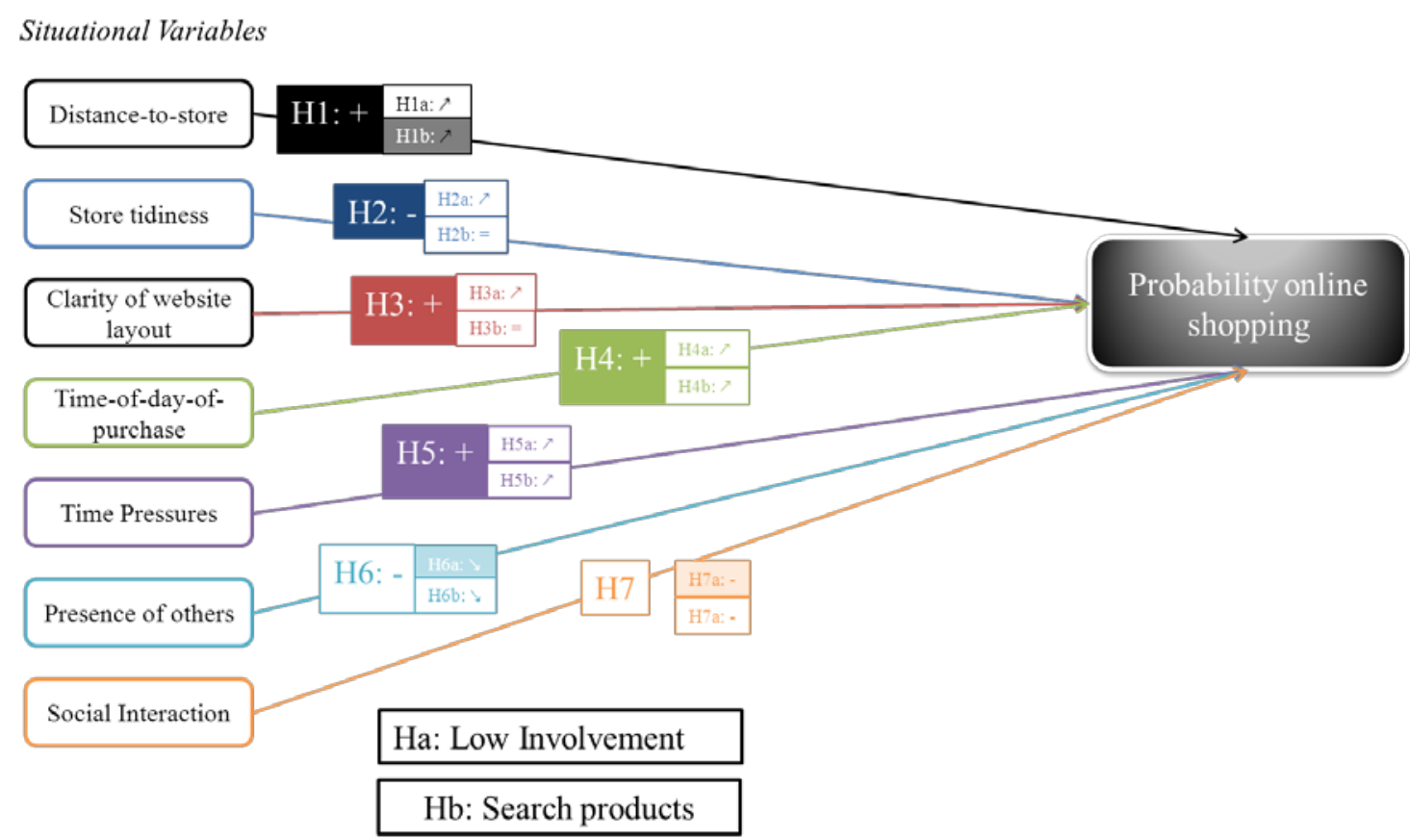




\section{Conclusions and implications}

Consumers' purchase channel choices have probably received more attention than any other area of consumer research since the arrival and rapid diffusion of the Internet in our society, as noted by Neslin et al. (2006) and Zhou et al. (2007). Interaction between channel choice and purchase context, however, has received scant attention.

Some purchase contexts can discourage the use of a specific purchase channel, even in consumers who fit the typical user profile. They can also increase the consumer's value perception of a given channel or drive preference for one versus another. The purchase context can also trigger or reinforce multichannel behaviour, with the result that, increasingly, consumers do not always select the same channel, even to purchase the same product. When asked to state which channels they use to purchase four different types of product in the last year, about 52\% of the survey participants who had bought books and IT products, $40 \%$ of those who had bought T-shirts and 30\% of those who had bought airline tickets had used more than one channel.

Although marketing managers cannot control all of these situational variables, an understanding of their impact on channel choice patterns would enable them to improve the sales procedures they use in the purchase channels they offer their customers, identify which new services to provide, and help in the design of publicity, promotion and merchandising strategies.

This paper makes three contributions to the literature. The first is an exploratory analysis to assess the relative importance of the different dimensions of situational variables, finding, in line with Nicholson et al (2002), that physical, social and timerelated dimensions are relevant to consumer preferences on virtual versus physical purchase channels.

The second contribution of this paper is the design of an experiment to identify which variables of the above dimensions are the key drivers of channel preference.Of all the situational variables that can influence the choice between online and offline channels, consumers' main concern is with clarity of organization, whatever the product category. Store untidiness is a factor that makes consumers turn to the online channel. A clearly laid out website also encourages online purchases. Thus, as well as taking extra care to maintain tidiness during opening hours, the managers of physical stores could 
make good use of ICT by using it to remove some of the effort and stress from the shopping process for their customers and thereby reduce any reluctance towards shopping in traditional stores. This could be done by providing screens at the entrance to enable customers to check product availability and characteristics in real time.

The enormous technological and interactive potential of the online environment not only enables firms to design functional and effective web site layouts and avoid interruptions of Internet traffic flow, it also offers them the opportunity to include tools to make the shopping process easier and more effective. The possibilities include the incorporation of features to enable consumers to customize the website to suit their requirements for each purchase process, thus satisfying one of the demands of online customers, which is for greater control in the purchase environment (Poole and O'Cass 2002). This will require consultation with other disciplines or areas of research dealing with the customer-computer interface from the programming and technical perspective. The use of data mining techniques will also enable managers to design profiles to streamline the customization process.

Our findings suggest that distance-to-store can predictably act as a stimulus to online purchase. Developments in mobile phone technology, which further simplify Internet access, may increase perceived distance-to-store in the mind of the consumer. However, if virtual store managers wish to take advantage of the distance factor, they need to work towards reducing the uncertainty in consumers generated by the intangibility of online products (they cannot feel, smell or taste them to check the texture and see whether apparent quality matches up to actual quality). One possibility is to maximize size, colour, movement and three-dimensional effects in order to provide the clearest possible images of their products. Even greater advantage could be gained from the distance factor by making it easier for consumers to return goods purchased online.

Relevant findings have also emerged with respect to the role played by the time factor in the purchase context. Irrespective of product category and urgency of purchase, the restrictions imposed by traditional store opening hours are another potential driver of online purchase intentions. At certain times of day, the consumer may delay the purchase decision until the following day, or use the online channel to purchase the product or at least locate and research the options. 
The decision to purchase online is also dependent on time pressures. Time-saving possibilities and the advantages of 24-hour shopping encourage consumers to shop online. One-click purchase buttons, intuitive search and browse options, satisfied customer testimonials, etc. can help to increase the advantages even further. The managers of traditional retail stores, meanwhile, might concentrate on finding ways to simplify and speed up the purchase process. In clothes stores, the answer might be to train staff to be sufficiently familiar with all the product lines in the store as to be able to provide individual advice to customers. In the case of bookshops, it might be to provide electronic book finders to enable customers to locate and obtain a synopsis of a book by typing in the title, name of author or a few key words; or to install automatic cash out facilities. The aim may be to incentivize the use of a particular channel or to boost the numbers of multichannel users, whose purchase and spending levels have been found to be higher than those of single-channel users (Ansari et al.2008, Chintagunta et al. 2009). Whatever the case, in addition to the above, communication and promotion campaigns will be needed to bring consumers' attention to the added value of each purchase channel in relation to the situational variables considered in this study.

The third contribution of this paper is its focus on the moderating impact of product category on the effects of situational variables. While past research has focused on single-category analyses, this paper considers four: high/low involvement goods and search/experience goods. The findings nevertheless remain inconclusive. Our findings can be summed up as follows. Distance-to-store has less of a dissuading effect when the consumer is considering the purchase of a search good than when considering that of an experience good. Furthermore, while the chance for social interaction is found to be a possible incentive for consumers to purchase high-involvement goods online, neither of the social variables considered was found to influence channel choice for the purchase of low-involvement goods. Virtual stores need to strive to create a more socially enriching shopping environment. While this is not yet the general trend, many companies are now using a sophisticated combination of telephone, e-mail, fax, Internet and interactive voice and data technology to provide support services that used to be impossible. Some online stores, for example, are monitoring their customers' web searches and then opening a chat window to enquire (just as they would in a real store) whether the customer needs any information about the articles being viewed. 
The empirical results failed to support the other hypotheses considered with respect to the moderating role of product category in the impact of situational variables. This could be a consequence of the experimental design, which defines product category not as a within-group but as a between-group factor, such that no channel choice scenario is presented to the same individuals for different product categories. In any event, with some improvement, our conceptual framework for testing the moderating effect of product category could be used to test these hypotheses in future research.

Finally, it should be noted that this study uses only two product classifications, thereby discarding other criteria suggested by the literature, such as hedonic versus utilitarian. Social interaction factors would probably have more influence on channel choice for the purchase of hedonic goods. Other potentially more important determinants include task-definition variables such as personal use versus gift scenarios. This is another key area for future research. 


\section{References}

Aberg, J. and Shahmenhri, N. The role of human web assistants in e-commerce: an analysis and a usability study. Internet Research: Electronic Networking Applications and Policy, 10, 2, 2000, 114-125.

AIMC.12th AIMC Internet User Survey. at: www.aimc.es

Akaah, I. P., Korgaonkar, P. K., and Daulatram, L. Direct marketing attitudes. Journal of Business Research, 34, 3, 1995, 211-219.

Alba, J., Lynch, J., Weitz, B., Janiszewski, C., Lutz, R., Sawyer, A., and Woods, S. Interactive home shopping consumer, retailer and manufacturer incentives to participate in electronic marketplaces. Journal of Marketing, 51, 3, 1997, 38-53.

Ansari, A., Mela, C., and Neslin, S. Customer Channel Migration. Journal of Marketing Research, 45, 1, 2008, 60-76.

Antil, J. H., Conceptualization and Operationalization of Involvement. Advances in Consumer Research, eds. Thomas C. Kinnear, Provo, UT: Association for Consumer Research, 11, 1984, 203-209.

Balasubramanian, S. Mail versus Mall: A Strategic Analysis of Competition between Direct Marketers and Conventional Retailers. Marketing Science, 17, 3, 1998, 181-195.

Beatty, S. E. and Smith, S. M. External Search Effort: An Investigation Across Several Product Categories. The Journal of Consumer Research, 14, 1, 1997, 83-95.

Belk. R. W. An Exploratory Assessment of Situational Effects in Buyer Behavior. Journal of Marketing Research, 11, 2, 1974, 156-63.

Belk. R. W. Situational Variables and Consumer Behavior. Journal of Consumer Research, 2, 3, 1975, 157-164.

Ben-Akiva, M., and Lerman, S. R. Discrete Choice Analysis: Theory and Application to Travel Demand. MIT Press, Cambridge, M.A., 1985.

Black N., Lockett A., Ennew C., Winklhofer H., and McKechnie S. Modelling consumer choice of distribution channels: An illustration from financial services. International Journal of Bank Marketing, 20, 4, 2002, 161-173.

Bone, P. F. Word-of-mouth effects on short-term and long-term product judgments. Journal of Business Research, 32, 3, 1995, 213-223.

Borges, A., Chebat, J-C.and Babin, B. J. Does a companion always enhance the shopping experience? Journal of Retailing and Consumer Services, 17, 4, 2010, 294299

Chintagunta, P. K., Chu, J. and Cebollada, J. Quantifying Transaction Costs in Online / Offline Grocery Channel Choice. Marketing Science, 31,1, 2012, 96-114.

Cortiñas, M., Chocarro, R., and Villanueva, M. L. Understanding multi-channel banking customers. Journal of Business Research, 63, 11, 2010, 1215-1221.

Dabholkar, P. A., and Bagozzi, R. P. An attitudinal model of technology-based selfservice: Moderating effects of consumer traits and situational factors. Journal of the Academy of Marketing Science, 30, 3, 2002, 184-201. 
Degeratu, A. M., Rangaswamy, A. and Wu, J. Consumer choice behavior in online and traditional supermarkets: The effects of brand name, price, and other search attributes. International Journal of Research in Marketing, 17, 1, 2000, 55-78.

DoubleClik Inc. Multi-channel shopping study-Holiday.www.doubleclick.net. 2004.

Downs, A., A theory of consumer efficiency. Journal of Retailing, 37, Winter, 1961, 612.

Forman, C., Ghose, A. and Goldfarb, A., Competition Between Local and Electronic Markets: How the Benefit of Buying Online Depends on Where You Live. Management Science, 55, 1, 2009, 47-57.

Gefen, D. and Straub, D.W. Managing user trust in B2C e-Services. E-Service Journal, 2, 2, 2003, 7-24.

Gehrt, K. C., Shim, S. Situational influence in the international marketplace: an examination of Japanese gift giving, Journal of Marketing Theory and Practice, 10, 1, 2002, 11-22.

Gehrt, C. K., and Yan, R. N. Situational, consumer, and retailer factors affecting Internet, catalog, and store shopping. International Journal of Retail \& Distribution Management, 32, 1, 2004, 5-18.

Greenwald, A.G. Within-subjects designs: To use or not to use? Psychological Bulletin, 83, 2, 1976, 314-320.

Grewal, D., Iyer, G.R. and Levy, M. Internet retailing: enablers, limiters and market consequences. Journal of Business Research, 57, 7, 2004, 703-713.

Hand, C., Dall'Olmo F., Harris, P., Singh, J., and Rettie, R. Online grocery shopping: the influence of situational factors. European Journal of Marketing, 4, 9/10, 2009, 1205-1219.

Hassanein, K. and Head, M. Manipulating perceived social presence through the web interface and its impact on attitude towards online shopping. International Journal of Human Computer Studies, 65, 8, 2007, 689-708.

Hensher, D.A., Rose, J. M., and Greene, W.H. Applied Choice Analysis: A Primer, 2005.Cambridge Univ. Press, Cambridge, UK.

Hostler, R. E., Yoon, V.Y. and Guimaraes, T., Assessing the impact of internet agent on end users' performance. Decision Support Systems, 41, 2005, 313-323.

Huang, Y. and Oppewal, H. Experimental Choice Analysis of Grocery Shopping: Why Consumers Hesitate to Shop Online. International Journal of Retail and Distribution Management, 34, 4/5, 2006, 334-353.

Hui, M. and Bateson, J. E.G. (1991). Perceived Control and the Effects of Crowding and Consumer Choice on the Service Experience. Journal of Consumer Research, 18, 3, 1991, 174-184.

Jain, S. P., Buchanan, B., and Maheswaran, D. Comparative versus non-comparative advertising: the moderating impact of pre-purchase attribute verifiability. Journal of Consumer Psychology, 9, 4, 2000, 2011-211.

Kamakura, W. A., and Russell, G. A Probabilistic Choice Model for Market Segmentation and Elasticity Structure. Journal of Marketing Research, 26, 4, 1989, 379-390. 
Kaufman-Scarborough, C. and Lindquist, J.D. E-shopping in a multiple channel environment. Journal of Consumer Marketing, 19, 4, 2002, 333-350.

Kiecker, P. and Hartman, C. L. Predicting buyer's selection of interpersonal sources: the role of strong ties and weak ties. Advances in Consumer Research, 21, 1994, 464-469.

King, M. F., and Balasubramanian, S. K. The effects of expertise, end goal, and product type on adoption of preference formation strategy. Journal of the Academy of Marketing Science, 22, 2, 1994, 146-159.

Kleijnen, M., de Ruyter, K. and Wetzels, M. an assessment of value creation in mobile service delivery and the moderating role of time consciousness. Journal of Retailing, 83, 1, 2007, 33-46.

Krugman, H. The Impact of Television Advertising: Earning without Involvement. Public Opinion Quarterly, 29, Fall, 1965, 349-56.

Kumar, N. and Benbasat, I. Para-social presence and communication capabilities of a Web site: a theoretical perspective. E-Service Journal, 1, 3, 2002, 5-24.

Laurent, G and Kapferer J. N. Measuring Consumer Involvement Profiles. Journal of Marketing Research, 22, 1, 1985, 41-53.

Lociacono, E. T., Watson, R. T., and Goodhue, D. L. WebQual: A Measure of Web Site Quality. Paper presented at the meeting of the American Marketing Association on the Marketing Theory and Applications, Chicago. American Marketing Association, 2002, 432-438.

Louviere, J. J., Hensher, D.A., and Swait, J.D. Stated Choice Methods. Analysis and Application, Cambridge University Press (2000).

Lurie, N. H. Decision making in information-rich environments: the role of information structure. The Journal of Consumer Research, 30, 4, 2004, 473-486.

Malhotra, N. K. Structural Reliability and Stability of Nonmetric Conjoint Analysis, Journal of Marketing Research, 199 -207.

Manganari, E. E., Siomkos G. J. and Vrechopoulos, A. P. Store atmosphere in web retailing. European Journal of Marketing, 43, 9/10, 2009, 1140-1153.

Mattson BE, Dubinsky A. J. Shopping patterns: An exploration of some situational determinants. Psychology \& Marketing 4,1987 47-62.

Meuter M. L., Ostrom A. L., Roundtree, R.I. and Bitner, M. J. Self-service technologies: Understanding Customer Satisfaction with Technology-Based Service Encounters. Journal of Marketing, 64, 3, 2000, 50-64.

Montoya-Weiss M. M., Voss, G. B, and Grewal, D. Determinants of online channel use and overall satisfaction with a relational multichannel service provider. Journal of the Academy of Marketing Science, 31, 4, 2003, 448-58.

Moore, G. C., and Benbasat, I. Integrating diffusion of innovations and theory of reasoned action models to predict utilization of information technology by end-users. Diffusion and Adoption of Information Technology, K. Kautz and Pries-Heje, J. (Eds.), Chapman \& Hall, London, 1996, 132-146.

Morales, A., Kahn, B. E., McAlister, L. and Broniarczyk, S. M. Perceptions of Assortment Variety: The Effects of Congruency Between Consumer's Internal and Retailer's External Organization. Journal of Retailing, 81, 2, 2005, 159-169. 
Morrison, P. D., and Roberts, J. H., Matching electronic distribution channels to product characteristics: the role of congruence in consideration set formation. Journal of Business Research, 41, 3, 1998, 223-9.

Nelson, P. Advertising as Information. Journal of Political Economy, 82, 4, 1974, 729754.

Nelson, P. Information and consumer behaviour. Journal of Political Economy, 77, 1970, 311-329.

Neslin, S. A., Grewal, D., Leghorn, R., Shankar, V., Teerling, M. L. Thomas, J. S., and Verhoef, PC Opportunities and Challenges in Multichannel Customer Management. Journal of Service Research, 2006, 9, 2, 95-112.

Nicholson, M., Clarke, I. and Blakemore, M. One brand, three ways to Shop: situational variables and multichannel consumer behaviour. International Review of Retail, Distribution and Consumer Research, 12, 2, 2002, 131-148.

Oppewal, H., Tojib, D.R. and Louvieris, P. Experimental analysis of consumer channelmix use. Journal of Business Research, 2012. Doi: 10.1016/j.jbusres.2012.02.002

Ortúzar, J. de D., Roncagliolo, D.A., and Velarde, U.C. Interactions and independence in stated preference modelling. In: Ortúzar, J. de D. (Ed.), Stated Preference Modelling Techniques. Perspectives 4, 2000. PTRC, London.

Peterson, R. A., Balasubramanian, S., \& Bronnenberg, B. J. (1997). Exploring the implications of the Internet for consumer Marketing. Journal of Marketing Science, 25, 329-346.

Poole, M. and O'Cass, A. The construct of control: assessment of shopping environments. Proceedings of the Australian and New Zealand Marketing Academy Conference (ANZMAC), 2002, 1771-1778.

Quester, P and Lim, A. L. Product involvement/brand loyalty: is there a link, Journal of Product \& Brand Management, 12, 1, 2003, 22 - 38

Raghunathan, R. and Corfman, K. Is Happiness Shared Doubled and Sadness Shared Halved? Social Influence on Enjoyment of Hedonic Experiences. Journal of Marketing Research, 43, August, 2006, 386-394.

Rao, A. R., and Bergen, M.E. Price premium variations as a consequence of buyers' lack of information. Journal of Consumer Research, 19, December, 1992, 412-423.

Richard, M. O. Modeling the impact of internet atmospherics on surfer behavior. Journal of Business Research, 58, 12, 2005, 1632-164

Schröder, H. and Zaharia, S. Linking multi-channel customer behaviour with shopping motives: an empirical investigation of a German retailer. Journal of Retailing and Consumer Services, 15, 2008, 452-468.

Sommer, R., Wynes, M. and Brinkley, G. Social facilitation effects in shopping behavior. Environment and Behavior, 24, 3, 1992, 285-297.

Swait, J., and Louviere, J. The Role of the Scale Parameter in the Estimation and Comparison of Multinomial Logit Models. Journal of Marketing Research, 30, August, 1993, 305-314. 
Turley, L. W. and Milliman, R. E. Atmospheric Effects on Shopping Behavior: A Review of the Experimental Evidence. Journal of Business Research, 49, 2, 2000, 193211.

Van der Heijden, H. Verhagen, T. and Creemers, M. Understanding online purchase intentions: contributions from technology and trust perspectives. European Journal of Information Systems, 12, 2003, 41-48.

Van Kenhove, P., De Wulf, K., and Van Waterschoot, W. The impact of task definition on store-attribute saliences and store choice. Journal of Retailing, 75, 1, 1999, 125-137.

Verhoef, P.C., and Langerak, F. Possible Determinants of Consumers' adoption of Electronic Grocery Shopping in the Netherlands. Journal of Retailing and Consumer Services, 8, 5, 2001, 275-285.

Wakefield, K. L. and Inman, J. J. Situational price sensitivity: the role of consumption occasion, social context and income. Journal of Retailing, 79, 4, 2003, 199-212.

Wang, Y. D. and Emurian, H.H. An overview of online trust: concepts, elements, and implications. Computers in Human Behavior, 21, 2005, 105-125.

Wang, C., Harris, J., and Patterson, P. G. Customer choice of self-service technology: The roles of situational influences and past experience. Journal of Service Management, 23, 1, 2012, 54-78.

Wang, D., and Li, J. Handling large numbers of attributes and/or levels in conjoint experiments, Geographical Analysis, 34, 2002, 350-362.

Wang, H. C., Pallister, J. G. and Foxall, G. R. Innovativeness and involvement as determinants of website loyalty: III. Theoretical and managerial contributions. Technovation, 26, 2006, 1374-1383.

West, P. M., and Broniarczyk, S. M. Integrating Multiple Opinions: The Role of Aspiration Level on Consumer Response to Critic Consensus. Journal of Consumer Research, 25, June, 1998, 38-51.

Westbrook, R.A. Product/Consumption-Based Affective Responses and Post-purchase Processes. Journal of Marketing Research, 24, 3, 1987, 258-270.

Wright, A. A., and Lynch, J. G. Communication effects of advertising versus direct experience when both search and experience attributes are present. Journal of Consumer Research, 21, 1995, 708-718.

Zaichkowsky, J. L. Measuring the Involvement Construct. The Journal of Consumer Research, 12, 3, 1985, 341-352.

Zhou, L., Dai, L., and Zhang, D. Online Shopping Acceptance Model - A Critical Survey of Consumer Factors in Online Shopping. Journal of Electronic Commerce Research, 8, 1, 2007, 41-62.

Zhu, L. Benbasat, I. and Jiang, Z. Investigating the role of presence in collaborative online shopping. Proceedings of the twelfth Americas Conference on Information Systems, Acapulco, Mexico, August, 2006. 